\title{
Genome Editing for Improving Crop Nutrition
}

\author{
Ai Nagamine ${ }^{1}$ and Hiroshi Ezura ${ }^{1,2 *}$ \\ ${ }^{1}$ Faculty of Life and Environmental Sciences, University of Tsukuba, Tsukuba, Japan, ${ }^{2}$ Tsukuba Plant Innovation Research Center, \\ University of Tsukuba, Tsukuba, Japan
}

OPEN ACCESS

Edited by:

Bing Yang,

University of Missouri, United States

Reviewed by:

Yanpeng Wang,

Institute of Genetics and Developmental Biology (CAS), China

*Correspondence: Hiroshi Ezura ezura.hiroshi.fa@u.tsukuba.ac.jp

Specialty section: This article was submitted to Genome Editing in Plants, a section of the journal

Frontiers in Genome Editing

Received: 07 January 2022

Accepted: 24 January 2022

Published: 09 February 2022

Citation:

Nagamine A and Ezura H (2022) Genome Editing for Improving Crop Nutrition.

Front. Genome Ed. 4:850104. doi: 10.3389/fgeed.2022.850104
Genome editing technologies, including CRISPR/Cas9 and TALEN, are excellent genetic modification techniques and are being proven to be powerful tools not only in the field of basic science but also in the field of crop breeding. Recently, two genome-edited crops targeted for nutritional improvement, high GABA tomatoes and high oleic acid soybeans, have been released to the market. Nutritional improvement in cultivated crops has been a major target of conventional genetic modification technologies as well as classical breeding methods. Mutations created by genome editing are considered to be almost identical to spontaneous genetic mutations because the mutation inducer, the transformed foreign gene, can be completely eliminated from the final genome-edited hosts after causing the mutation. Therefore, genome-edited crops are expected to be relatively easy to supply to the market, unlike GMO crops. On the other hand, due to their technical feature, the main goal of current genome-edited crop creation is often the total or partial disruption of genes rather than gene delivery. Therefore, to obtain the desired trait using genome editing technology, in some cases, a different approach from that of genetic recombination technology may be required. In this mini-review, we will review several nutritional traits in crops that have been considered suitable targets for genome editing, including the two examples mentioned above, and discuss how genome editing technology can be an effective breeding technology for improving nutritional traits in crops.

Keywords: genome editing, nutritional improvement, crops, CRISPR/Cas9, TALEN, high GABA tomato, high oleic soybean oil

\section{INTRODUCTION}

The demand for food is increasing due to global population growth; the worldwide population is projected to require a 1.7 -fold increase in cereals and a 1.8 -fold increase in livestock products by 2050 (MAFF, Japan, 2019). Therefore, efforts should be made to increase food production using all possible methods. In addition, changing global dietary habits (from a starch-based diet to a high-fat, high-protein diet) and the aging of the population have led to an increase in lifestyle-related diseases, resulting in ever-increasing health concerns worldwide. Medical solutions are direct, but they are costly and not widely applicable. Therefore, it is important to address these lifestyle-related diseases with comprehensive nutritional intake through food. For these reasons, improving crop nutrition has become an important national policy in many countries. However, with conventional breeding techniques, it usually takes more than 10 years to produce a commercial cultivar that includes the desired traits. This is because many generations of crosses and backcrosses are generally required to accumulate a set of QTLs for the target traits. Some crop species have accumulated useful genetic resources that provide an important basis for creating new superior varieties with excellent genetic 
tools. However, it is difficult to overcome the time constraint, and time is one of the major hurdles in responding to ever-changing international needs.

The advent of genome editing technologies (ZFN, TALEN, CRISPR/Cas9, etc.) has attracted a great deal of attention because the remove the limitations of conventional breeding methods (for more information on each technology in crops, we recommend reading the following reviews: Rojas-Vásquez and Gatica-Arias, 2019; Matres et al., 2021). These technologies are capable of creating precise mutations in targeted genes, and their use in the field of crop breeding is on the rise. Some of the crops that are currently being produced include disease- and stress-tolerant crops, high oleic acid soybeans, and high GABA-accumulating tomatoes. If the advantages of genome editing are utilized to the fullest, it will be possible to modify the accumulation of target functional components while retaining $100 \%$ of the host's other useful traits by controlling the expression and modifying the functions of genes involved in the pre- and postmetabolism of the target functional components. Therefore, genome editing technology is expected to be an effective breeding method to modify the metabolism of nutritional functional components, especially for crops whose biosynthetic systems are known.

In this mini-review, we discuss the current status of developmental research on the improvement of functional components in crops using genome editing technology and provide an outlook for the future.

\section{IMPROVING NUTRIENT COMPOSITION BY CONTROLLING GENE EXPRESSION}

One of the targets of genome editing is to regulate the expression level of genes involved in the metabolism of the target nutrient or undesirable substance itself. In this case, there are two targets: one is as far upstream of the CDS as possible, and the other is the untranslated region involved in regulating expression, including the $5^{\prime} \mathrm{UTR}$. The former target induces a frameshift as far upstream as possible of the CDS and results in a termination codon that is not normally present, thereby achieving incomplete translation by premature termination of translation. The latter target aims to regulate the expression level of target genes and proteins by mutating the untranslated regions of genes involved in the regulation of transcription and expression levels.

\section{Development of High Oleic Soybean Oil}

Soybean oil contains high amounts of polyunsaturated fatty acids such as linoleic acid and linolenic acid and low amounts of monounsaturated fatty acids such as oleic acid. Soybean oil is hydrogenated to improve its fatty acid composition, but this process produces trans-fatty acids that are rather harmful to human health (Ascherio et al., 2008). In 2019, Calyxst (Minnesota, United States) developed a new soybean with more than $80 \%$ oleic acid (similar to olive oil) using TALEN and launched Calyno ${ }^{\mathrm{TM}}$, the world's first genome-edited soybean with improved oleic acid content. They achieved the goal of more than $80 \%$ oleic acid and less than $3 \%$ linolenic acid by knocking out the fatty acid desaturase FAD2-1A, FAD2-1B and FAD3A exons, which metabolize oleic acid to linoleic acid, using TALEN (Haun et al., 2014; Demorest et al., 2016). This strategy involves knocking out genes involved in the downstream metabolism of oleic acid synthesis in the soybean fatty acid metabolic pathway that essentially leads to linolenic acid, thereby increasing the accumulation of the intermediate product oleic acid and inhibiting the downstream synthesis of linolenic acid and linoleic acid.

\section{OTHER EXAMPLES}

Similar genome editing has been carried out in many crops and many genes, including knockout of the vacuolar invertase gene $V I n v$, which produces reducing sugars responsible for acrylamide production in potatoes (Clasen et al., 2016), and knockout of the PPO gene in mushrooms (Waltz, 2016a) (Table 1). The strategy of targeting the CDS to induce frameshifting often results in a simple disruption of the target gene, and even if the structure and function of the protein encoded by the target gene are not clear, it is easy to obtain the desired phenotype. The ease of application is one of the reasons why this strategy has been used in many cases. On the other hand, the traits that can be altered by this strategy are limited to those that occur when the molecular biological events that the target gene is responsible for are restricted, such as the repression of the synthesis or degradation of specific substances, repression of the conversion to downstream metabolites, repression of the transport to specific compartments, and so on. However, for the nutritional improvement of crops, when the goal is to increase the synthesis and accumulation of the target product, sometimes the "suppressive" modification described above is not sufficient to meet market needs.

\section{Possibility of Regulating Expression by Improving the Untranslated Region}

The transcriptional efficiency of genes is mainly controlled by the promoter region in the $5^{\prime} \mathrm{UTR}$ and the terminator region in the $3^{\prime}$ UTR. In addition, there are transcriptional control regions called enhancers in the upstream and intergenic regions of genes. In the introns of some genes, there are also miRNAs that control or inhibit transcription. Furthermore, some transcribed mRNAs contain translation control regions (uORFs) that inhibit the translation of mRNAs, and in fact, there are some successful cases where vitamin $\mathrm{C}$ contents have been improved (Li et al., 2018c; Zhang et al., 2018). By targeting these elements and causing genomic mutations, it is possible to suppress or overexpress their expression levels without disrupting the CDS of the target gene. To date, there are few reports of genome editing targeting these elements, but the Supplementary Table S1 summarizes the most likely examples. Although not within the scope of this review because crop nutrition improvement was not the target, a study in rice demonstrated that precise multiple-base editing at miRNA target sites is possible (Ohtsuki et al., 2018). 
TABLE 1 | Applications of CRISPR/Cas9 in major crop species to improve nutritional contents.

\begin{tabular}{|c|c|c|c|c|c|c|c|}
\hline $\begin{array}{l}\text { Common } \\
\text { name }\end{array}$ & Phenotype & Target gene & $\begin{array}{l}\text { Target } \\
\text { region }\end{array}$ & $\begin{array}{l}\text { GE result on } \\
\text { target } \\
\text { expression } \\
\text { or } \\
\text { activity }\end{array}$ & $\begin{array}{c}\text { GE } \\
\text { technique }\end{array}$ & $\begin{array}{l}\text { Molecular function of } \\
\text { the target gene }\end{array}$ & References \\
\hline Rice & $\begin{array}{l}\text { increased content of } \\
\text { resistant starch }\end{array}$ & SBEI and SBEIlb & CDS & DOWN & $\begin{array}{l}\text { CRISPR/ } \\
\text { Cas9 }\end{array}$ & Regulate amylose contents & Sun et al. (2017) \\
\hline Rice & $\begin{array}{l}\text { low cesium } \\
\text { accumulation }\end{array}$ & OsHAK-1 & CDS & DOWN & $\begin{array}{l}\text { CRISPR/ } \\
\text { Cas9 }\end{array}$ & Cs + uptake in roots & $\begin{array}{l}\text { Nieves-Cordones } \\
\text { et al. (2017) }\end{array}$ \\
\hline Sorghum & $\begin{array}{l}\text { increased digestibility } \\
\text { and protein quality }\end{array}$ & k1C gene family & n.i. & DOWN & $\begin{array}{l}\text { CRISPR/ } \\
\text { Cas9 }\end{array}$ & $\alpha$-kafirins (major storage proteins) & Li et al. (2018a) \\
\hline $\begin{array}{l}\text { Bread } \\
\text { wheat }\end{array}$ & low gluten content & sgAlpha-1 sgAlpha-2 & CDS & DOWN & $\begin{array}{l}\text { CRISPR/ } \\
\text { Cas9 }\end{array}$ & the immunoreactive $a$-gliadin & $\begin{array}{l}\text { Sánchez-León et al. } \\
\text { (2018) }\end{array}$ \\
\hline Soybean & $\begin{array}{l}\text { altered fatty acids } \\
\text { levels }\end{array}$ & $\begin{array}{l}F A D 2-1 A \text { and } \\
F A D 2-1 B\end{array}$ & CDS & DOWN & TALEN & Fatty acid desaturase 2 & $\begin{array}{l}\text { Haun et al. (2014); } \\
\text { Demorest et al. (2016) }\end{array}$ \\
\hline Peanut & $\begin{array}{l}\text { increased oleic acid } \\
\text { content }\end{array}$ & $F A D 2 A$ and $F A D 2 B$ & CDS & DOWN & $\begin{array}{l}\text { CRISPR/ } \\
\text { Cas9 }\end{array}$ & $\begin{array}{l}\text { Converts oleic acid to linoleic acid } \\
\text { gene coding sequences }\end{array}$ & Yuan et al. (2019) \\
\hline Peanut & $\begin{array}{l}\text { 0.5-twofold increase in } \\
\text { the oleic acid content }\end{array}$ & FAD2 & CDS & DOWN & TALEN & $\begin{array}{l}\text { Converts oleic acid to linoleic acid } \\
\text { gene coding sequences }\end{array}$ & Wen et al. (2018) \\
\hline $\begin{array}{l}\text { Sweet } \\
\text { potato }\end{array}$ & $\begin{array}{l}\text { decreased amylose } \\
\text { content }\end{array}$ & GBSSI & CDS & DOWN & $\begin{array}{l}\text { CRISPR/ } \\
\text { Cas9 }\end{array}$ & $\begin{array}{l}\text { Granule-bound starch } \\
\text { biosynthesis }\end{array}$ & Wang et al. (2019) \\
\hline $\begin{array}{l}\text { Sweet } \\
\text { potato }\end{array}$ & $\begin{array}{l}\text { decreased } \\
\text { amylopectin content; } \\
\text { increased amylose } \\
\text { content }\end{array}$ & SBEll & CDS & DOWN & $\begin{array}{l}\text { CRISPR/ } \\
\text { Cas9 }\end{array}$ & Starch branching for amylopectin & Wang et al. (2019) \\
\hline Potato & decreased browning & PP02 & CDS & DOWN & $\begin{array}{l}\text { CRISPR/ } \\
\text { Cas9 }\end{array}$ & $\begin{array}{l}\text { Converts phenolic substrates to } \\
\text { quinones }\end{array}$ & González et al. (2020) \\
\hline Potato & $\begin{array}{l}\text { decreased steroidal } \\
\text { glycoalkaloid content }\end{array}$ & $16 D O X$ & CDS & DOWN & $\begin{array}{l}\text { CRISPR/ } \\
\text { Cas9 }\end{array}$ & $\begin{array}{l}\text { Steroidal glycoalkaloid } \\
\text { biosynthesis }\end{array}$ & Nakayasu et al. (2018) \\
\hline Potato & $\begin{array}{l}\text { reduced levels of } \\
\text { acrylamide }\end{array}$ & Vinv & CDS & DOWN & TALEN & $\begin{array}{l}\text { Accumulation of reducing sugars } \\
\text { which cause acrylamide } \\
\text { accumulation. }\end{array}$ & Clasen et al. (2016) \\
\hline Tomato & $\begin{array}{l}\text { reduced concentration } \\
\text { of } \gamma \text {-aminobutyric acid }\end{array}$ & $\begin{array}{l}\text { GABA-TP1, GABA- } \\
\text { TP2, GABA-TP3, } \\
\text { CAT9 and SSADH }\end{array}$ & CDS & DOWN & $\begin{array}{l}\text { CRISPR/ } \\
\text { Cas9 }\end{array}$ & $\begin{array}{l}\text { Essential genes for the } \gamma^{-} \\
\text {aminobutyric acid (GABA) } \\
\text { pathway }\end{array}$ & Li et al. (2018b) \\
\hline Tomato & Pink tomatoes & MYB12 & CDS & DOWN & $\begin{array}{l}\text { CRISPR/ } \\
\text { Cas9 }\end{array}$ & Flavonoids Metabolic Pathways & $\begin{array}{l}\text { Deng et al. (2018); } \\
\text { Zhu et al. (2019) }\end{array}$ \\
\hline Tomato & $\begin{array}{l}\text { oprange tomatoes and } \\
\text { yellow tomatoes, } \\
\text { respectively }\end{array}$ & CRTISO or PSY1 & CDS & DOWN & $\begin{array}{l}\text { CRISPR/ } \\
\text { Cas9 }\end{array}$ & Carotenoids Metabolic Pathways & $\begin{array}{l}\text { Dahan-Meir et al. } \\
\text { (2018) }\end{array}$ \\
\hline Tomato & purple tomatoes & SIANT1 & $\begin{array}{l}\text { Promo- } \\
\text { ter }\end{array}$ & UP & $\begin{array}{l}\text { TALEN and } \\
\text { CRISPR/ } \\
\text { Cas9 }\end{array}$ & Anthocyanin biosynthesis & Čermák et al. (2015) \\
\hline Tomato & $\begin{array}{l}5.1 \text {-fold increase in the } \\
\text { lycopene content }\end{array}$ & $\begin{array}{l}S G R 1, L C Y-E, B / C \\
L C Y-B 1, \text { and } L C Y-B 2\end{array}$ & CDS & DOWN & $\begin{array}{l}\text { CRISPR/ } \\
\text { Cas9 }\end{array}$ & Carotenoids Metabolic Pathways & Li et al. (2018d) \\
\hline * Tomato & $\begin{array}{l}\text { increased carotenoid, } \\
\text { lycopene, and } \beta \text { - } \\
\text { carotene }\end{array}$ & $\begin{array}{l}\text { SIDDB1, SIDET1, } \\
\text { SICYC-B }\end{array}$ & CDS & DOWN & Target-AID & Carotenoids Metabolic Pathways & Hunziker et al. (2020) \\
\hline * Tomato & $\begin{array}{l}\text { sevenfold to } 15 \text {-fold } \\
\text { increase in GABA } \\
\text { accumulation }\end{array}$ & SIGAD2 and SIGAD3 & $\begin{array}{l}\text { CDS } \\
\text { (AID) }\end{array}$ & UP & $\begin{array}{l}\text { CRISPR/ } \\
\text { Cas9 }\end{array}$ & $\begin{array}{l}\text { Aminobutiric acid Metabolic } \\
\text { Pathways }\end{array}$ & Nonaka et al. (2017) \\
\hline $\begin{array}{l}\text { Wild } \\
\text { tomato }\end{array}$ & $\begin{array}{l}\text { increased vitamin } \mathrm{C} \\
\text { content }\end{array}$ & GGPI & uORF & UP & $\begin{array}{l}\text { CRISPR/ } \\
\text { Cas9 }\end{array}$ & Vitamin C metabolism & Li et al. (2018b) \\
\hline Tomato & $\begin{array}{l}\text { decreased } \\
\text { anthocyanin content }\end{array}$ & SIANT2, SIAN2-like & CDS & DOWN & $\begin{array}{l}\text { CRISPR/ } \\
\text { Cas9 }\end{array}$ & Anthocyanin biosynthesis & $\begin{array}{l}\text { Yan et al. (2020); Zhi } \\
\text { et al. (2020) }\end{array}$ \\
\hline Tomato & $\begin{array}{l}\text { decreased } \\
\text { anthocyanin content }\end{array}$ & $H Y S$ & CDS & DOWN & $\begin{array}{l}\text { CRISPR/ } \\
\text { Cas9 }\end{array}$ & $\begin{array}{l}\text { Anthocyanin biosynthesis in } \\
\text { response to light }\end{array}$ & Qiu et al. (2019) \\
\hline Tomato & $\begin{array}{l}\text { increased } \\
\text { phenylalanine-derived } \\
\text { volatile content }\end{array}$ & FLORAL4 & CDS & & $\begin{array}{l}\text { CRISPR/ } \\
\text { Cas9 }\end{array}$ & $\begin{array}{l}\text { Regulates phenylalanine-derived } \\
\text { volatiles in fruit }\end{array}$ & Tikunov et al. (2020) \\
\hline Tomato & $\begin{array}{l}\text { decreased volatile } \\
\text { organic compounds }\end{array}$ & $R I N$ & CDS & DOWN & $\begin{array}{l}\text { CRISPR/ } \\
\text { Cas9 }\end{array}$ & Ripening control via ethylene & $\begin{array}{l}\text { Ito et al. (2017); Zhi } \\
\text { et al. (2020) }\end{array}$ \\
\hline Tomato & SSC, fiber, fructose, & $L 1 L 4$ & CDS & DOWN & ZFN & Metabolite pathway & Gago et al. (2017) \\
\hline
\end{tabular}

(Continued on following page) 
TABLE 1 | (Continued) Applications of CRISPR/Cas9 in major crop species to improve nutritional contents.

\begin{tabular}{|c|c|c|c|c|c|c|c|}
\hline $\begin{array}{l}\text { Common } \\
\text { name }\end{array}$ & Phenotype & Target gene & $\begin{array}{l}\text { Target } \\
\text { region }\end{array}$ & $\begin{array}{l}\text { GE result on } \\
\text { target } \\
\text { expression } \\
\text { or } \\
\text { activity }\end{array}$ & $\begin{array}{c}\text { GE } \\
\text { technique }\end{array}$ & $\begin{array}{l}\text { Molecular function of } \\
\text { the target gene }\end{array}$ & References \\
\hline & $\begin{array}{l}\text { phenol, carotene, } \\
\text { oxalic acid }\end{array}$ & & & & & & \\
\hline $\begin{array}{l}\text { Tomato/ } \\
\text { wild tomato }\end{array}$ & high lycopene content & сусB & CDS & DOWN & $\begin{array}{l}\text { CRISPR/ } \\
\text { Cas9 }\end{array}$ & Metabolite pathway & Zsögön et al. (2018) \\
\hline Eggplant & decreased browning & $\begin{array}{l}\text { PP04, PPOS, and } \\
\text { PP06 }\end{array}$ & CDS & DOWN & $\begin{array}{l}\text { CRISPR/ } \\
\text { Cas } 9\end{array}$ & $\begin{array}{l}\text { Converts phenolic substrates to } \\
\text { quinones }\end{array}$ & Maioli et al. (2020) \\
\hline Grape & $\begin{array}{l}\text { decreased tartaric acid } \\
\text { content }\end{array}$ & $I d n D H$ & CDS & DOWN & $\begin{array}{l}\text { CRISPR/ } \\
\text { Cas } 9\end{array}$ & $\begin{array}{l}\text { Tartaric acid biosynthesis } \\
\text { Vegetables }\end{array}$ & Ren et al. (2016) \\
\hline Carrot & $\begin{array}{l}\text { decreased } \\
\text { anthocyanin content }\end{array}$ & $\mathrm{F} 3 \mathrm{H}$ & CDS & DOWN & $\begin{array}{l}\text { CRISPR/ } \\
\text { Cas } 9\end{array}$ & Anthocyanin biosynthesis & $\begin{array}{l}\text { Klimek-Chodacka } \\
\text { et al. (2018) }\end{array}$ \\
\hline $\begin{array}{l}\text { Brassica } \\
\text { rapa }\end{array}$ & $\begin{array}{l}\text { decreased fructose, } \\
\text { glucose, and increase } \\
\text { sucrose contents }\end{array}$ & BrOG1A and BrOG1B & CDS & DOWN & $\begin{array}{l}\text { CRISPR/ } \\
\text { Cas } 9\end{array}$ & Primary metabolism & Jiang et al. (2020) \\
\hline Rapeseed & $\begin{array}{l}\text { increased seed oil } \\
\text { content }\end{array}$ & SFAR4 and SEARS & CDS & DOWN & $\begin{array}{l}\text { CRISPR/ } \\
\text { Cas9 }\end{array}$ & Oil degradation & $\begin{array}{l}\text { Karunarathna et al. } \\
\text { (2020) }\end{array}$ \\
\hline Rapeseed & $\begin{array}{l}\text { increased oleic acid } \\
\text { content; decreased } \\
\text { linoleic and linolenic } \\
\text { acid contents }\end{array}$ & FAD2 & CDS & DOWN & $\begin{array}{l}\text { CRISPR/ } \\
\text { Cas } 9\end{array}$ & Fatty acid biosynthesis & Okuzaki et al. (2018) \\
\hline $\begin{array}{l}\text { Chinese } \\
\text { kale }\end{array}$ & $\begin{array}{l}\text { yellow color of Chinese } \\
\text { kale with improved } \\
\text { market prospects }\end{array}$ & BoaCRTISO & CDS & DOWN & $\begin{array}{l}\text { CRISPR/ } \\
\text { Cas } 9\end{array}$ & Carotenoid biosynthesis & Sun et al. (2020) \\
\hline Lettuce & $\begin{array}{l}\text { increased oxidation } \\
\text { stress tolerance and } \\
\text { ascorbate content }\end{array}$ & LsGGP2 & uORF & UP & $\begin{array}{l}\text { CRISPR/ } \\
\text { Cas9 }\end{array}$ & $\begin{array}{l}\text { Deleted uORFs of LsGGP2 to } \\
\text { increase the translation of mRNAs }\end{array}$ & Zhang et al. (2018) \\
\hline Banana & $\begin{array}{l}\text { increased F-carotene } \\
\text { content }\end{array}$ & LCYe & CDS & DOWN & $\begin{array}{l}\text { CRISPR/ } \\
\text { Cas } 9\end{array}$ & B-carotene metabolism & Kaur et al. (2020) \\
\hline Mush-room & decreased browning & $P P O$ & CDS & DOWN & $\begin{array}{l}\text { CRISPR/ } \\
\text { Cas9 }\end{array}$ & $\begin{array}{l}\text { Converts phenolic substrates to } \\
\text { quinones }\end{array}$ & $\begin{array}{l}\text { Waltz, (2016b), } \\
\text { *review }\end{array}$ \\
\hline $\begin{array}{l}\text { Pome- } \\
\text { granate }\end{array}$ & $\begin{array}{l}\text { unique accumulation of } \\
\text { gallic acid 3-0- and 4- } \\
\text { 0-glucosides }\end{array}$ & $\begin{array}{l}\text { PgUGT84A23 and } \\
\text { PgUGT84A24 }\end{array}$ & CDS & DOWN & $\begin{array}{l}\text { CRISPR/ } \\
\text { Cas9 }\end{array}$ & $\begin{array}{l}\text { UDP-dependent } \\
\text { glycosyltransferases (UGTs) } \\
\text { enzymes with overlapping } \\
\text { activities in B-glucogallin } \\
\text { biosynthesis }\end{array}$ & Chang et al. (2019) \\
\hline
\end{tabular}

\section{IMPROVING NUTRIENT COMPOSITION BY REGULATING GENE FUNCTION}

Another goal of genome editing is to regulate the functions of proteins encoded by genes involved in the metabolism of a nutrient of interest or an unfavorable substance. In this case, the target may be the active center of the enzyme, the binding region of a ligand, or the activity control domain. Various patterns are possible depending on the combination of the physiological and structural properties of the target protein and the target trait.

\section{Development of Tomatoes With High Accumulation of GABA}

Tomatoes have been an excellent source of GABA among crops (Briguglio et al., 2018; Gramazio et al., 2020), and they are also a major crop commonly eaten around the world.

Sanatech Seed Co., Ltd. (Tsukuba, Japan) launched the first genome-edited tomato in Japan, "Sicilian Rouge High GABA", in
2021. This high-GABA tomato contains approximately four to five times the amount of GABA found in ordinary tomatoes. Considering that the high GABA tomatoes (without genome editing technology) available on the market until now contained approximately 1.5 times more GABA, this increase in the GABA content is a revolutionary improvement. CRISPR/ Cas9 genome editing, which is responsible for this increase, targets the autoinhibitory domain (AID) on the C-terminal side of GAD3, an enzyme involved in the biosynthesis of GABA (Nonaka et al., 2017). By inducing a frameshift in this autoinhibitory domain, early termination of translation occurred, and the autoinhibitory domain of GAD3 was excised (Nonaka et al., 2017). This strategy increases the enzymatic activity per molecule involved in GABA biosynthesis by eliminating inhibitors of $G A D 3$, whose activity is normally suppressed, without modifying the expression level of GAD3 itself.

\section{Other Examples}

As mentioned earlier, when modifying the function of a gene by genome editing, it is necessary to know the function of the protein or 


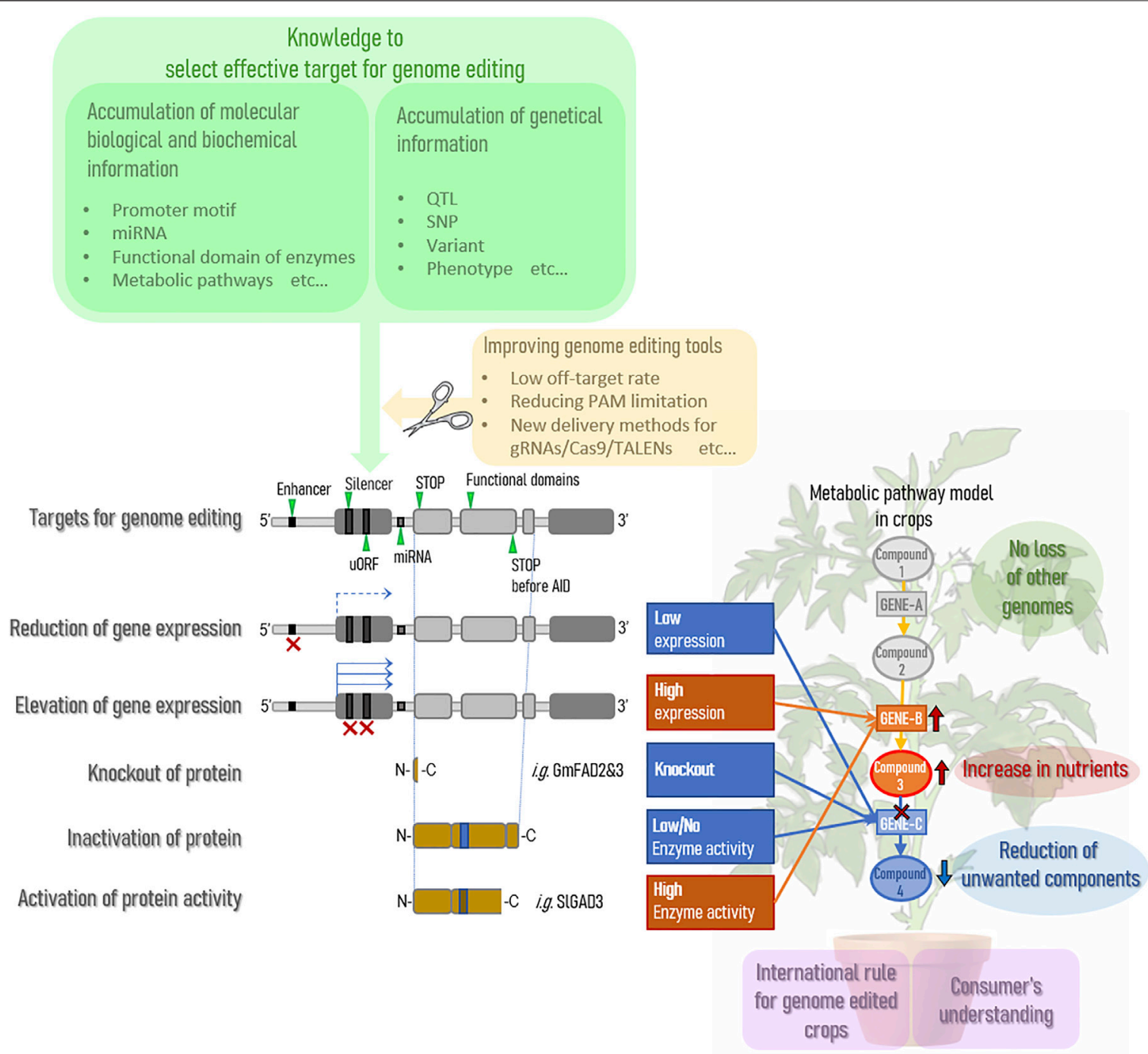

FIGURE 1 | Current situation on gene editing for enhanced nutrition in crops.

peptide encoded by the gene at the molecular level. The fact that there are far fewer examples of genome editing that have actually been implemented and have been effective compared to genome editing for knockout purposes (Table 1, asterisks) makes it easy to imagine the many challenges that need to be overcome. However, TARGET-AID has proven that it is possible to reproduce amino acid substitution mutations and obtain phenotypes by genome editing technology when the mutation is known (Hunziker et al., 2020).

\section{Understanding the Molecular Mechanism of Protein Function Regulation is Necessary for Controlling Gene Function by Genome \\ Editing}

In many cases, the normal function of a protein is achieved by a complex interplay of various factors, including the regulatory conditions of the active/inactive form. Therefore, the selection of targets for genome editing requires both molecular biological and biochemical knowledge of molecular mechanisms such as protein domain structure, protein-protein interactions, and activation control by feedback/feed-forward regulation.

On the other hand, genome editing can be useful for basic research to obtain such knowledge. Compared to conventional gene transfer methods (e.g., overexpression and RNA interference), genome editing has the advantage of removing the effects of foreign genes and finely modifying the targets at the domain and base levels, which is the same advantage that genome editing brings to crop breeding.

\section{FUTURE PROSPECTS AND CHALLENGES}

Genome editing technology is expected to expand as a way to improve the nutritional status of agricultural crops. Currently, 
many QTLs have accumulated in crops on the market through breeding, and genome editing technology is expected to improve the nutritional status of crops without compromising almost $100 \%$ of these useful QTLs. In other words, it can dramatically improve the effort to maintain QTLs by backcrossing and greatly reduce the time and cost of new breeding endeavors. However, there are several points that need to be improved before stable practical applications can be achieved. A summary is provided in Figure 1.

\section{It is Necessary to Improve the Technology to Modify the Target Genes More Precisely} Current genome editing technologies cannot completely eliminate the risk of off-target effects. To overcome this weakness, various challenges are being addressed to improve the off-target rate (Manghwar et al., 2020), including the identification of factors affecting the occurrence of off-target effects (Modrzejewski et al., 2020) and the development of CRISPR/Cas type I-D (Osakabe et al., 2020). When specific motifs are already known in the promoter region, the need to substitute arbitrary bases is expected to increase and improvements in nickase and base editing technologies (Nishida et al., 2016; Sakata et al., 2019) will be increasingly required; these improvements will be accelerated as our understanding of the molecular mechanisms of key trait expression increases. In addition, when using the CRISPR/ Cas9 system, a PAM sequence is currently required in the vicinity of the region of the target gene for which genome editing is desired; however, this is a major barrier to target selection. Currently, the challenge is to improve and eliminate this limitation of PAM sequences (Collias and Beisel, 2021).

\section{Understanding the Molecular Mechanism of Expression for Important Traits in Target Crops is Necessary}

In the future, as the accuracy of the technology for modifying target genes improves, the effect of genome editing can be maximized by controlling point (SNP)-level mutations for efficient expression of traits. For this purpose, it is more important to understand the underlying molecular mechanisms. Thus, it will become increasingly important to collect and store diverse genetic resources and analyze them to accumulate more basic research knowledge on the target crop and more SNP information related to phenotypes.

\section{There is a Need to Establish Rules for Genome Editing Crops in Each Country}

As we have discussed, since the discovery of the CRISPR/Cas9 mechanism in 2012, the progress of genome editing and its introduction into basic and applied science has accelerated worldwide. For the legality of this technology to persist, international rules must be generated quickly and appropriately.

Genome editing can be broadly classified into three categories depending on the type of mutation being introduced: SDN-1 uses nonhomologous end joining (NHEJ) to make relatively small deletions, insertions, and base substitutions; SDN-2 uses a species own homologous region as a template for homologous recombination repair (HDR); and $\mathrm{SDN}-3$ introduces genes from outside of the species for repair. For each of these three types, there is currently an international debate on whether genome-edited crops should be treated as recombinant (GM) or nonrecombinant (non-GM). In fact, the treatment of genomeedited crops varies from country to country, with many European countries treating genome-edited crops in a more restrictive manner. In this context, in 2020, EFSA reported its view that the SDN-1 and SDN-2 types are not subject to risk assessment if they do not contain exogenous DNA (Naegeli et al., 2020).

In addition, on april 29, 2021, the European Commission published the results of its review of the place of "new genomic technologies (NGTs)" in EU law, which strongly suggests that there are limits to the ability of existing legislation to apply to NGTs and their products and that legislation needs to be adapted to scientific and technological advances (https://ec.europa.eu/ food/plants/genetically-modified-organisms/new-techniquesbiotechnology/ec-study-new-genomic-techniques_en).

Furthermore, on 29 September 2021, a statement was issued by the UK government on its plans to lift GMO-like restrictions on genome editing (https://www.gov.uk/government/consultations/ genetic-technologies-regulation/outcome/genetic-technologiesregulation-government-response).

While we should continue to monitor the views of other countries, the fact that the high oleic soybeans and high GABA tomatoes, which are categorized as SDN-1, have finally reached the market and are now available to the general public is a large step in the history of genome-edited crops and is certainly a major benchmark for countries to formulate future directions and appropriate rules.

\section{There is a Need to Improve Consumer Understanding of Genome-Edited Crops}

Needless to say, the ultimate recipients of the developed genomeedited crops are consumers. When ordinary consumers purchase genome-edited crops at supermarkets, they are most likely to be concerned about safety. For consumers to understand the safety of genome-edited crops, it is necessary to communicate as correctly and clearly as possible how genome-edited crops were developed, why they are safe, what makes them different from conventional crops, and what makes them different from GM crops. Sanatech Seed Co., Ltd., the company that developed the high GABA tomato, has established two websites, one in Japanese and one in English, with Q\&A pages for general questions, thus creating a platform of information that ordinary consumers can refer to when they are curious (https://sanatech-seed.com/en/). Web tools such as social networking services (SNSs), which are currently undergoing remarkable technological innovation, can be used as tools that provide opportunities for multidirectional communication, unlike traditional one-way mass media. Therefore, by using these new tools, we may be able to accomplish the task of information dissemination more effectively. On the other 
hand, until the new products created by this new technology are widely accepted by the public, consumers may be need to select and examine more appropriate information without getting caught up in sensational topics. Scientists and the international community should remain equally (or even more) loyal to the consumer's motivation to understand these technologies.

\section{DISCUSSION}

Just 8 years after the publication of the first paper on CRISPR/ Cas9 by Charpentier and Doudna in 2012 (Jinek et al., 2012), the Nobel Prize in Chemistry was awarded to CRISPR/Cas9 in 2020. The launch of the first CRISPR/Cas9 genome-edited crop in 2021 is a testament to the superiority of CRISPR/Cas9 as a crop breeding technology and reflects the current pressure on the breeding field and the international community to solve food supply problems. This Nobel Prize-winning genome editing technology is anticipated to help improve global nutrition.

\section{REFERENCES}

Ascherio, A., Katan, M. B., Zock, P. L., Stampfer, M. J., and Willett, W. C. (1999). Trans Fatty Acids and Coronary Heart Disease. N. Engl. J. Med. 340, 1994-1998. doi:10.1056/NEJM199906243402511

Briguglio, M., Dell'Osso, B., Panzica, G., Malgaroli, A., Banfi, G., and Zanaboni Dina, C. (2018). Dietary Neurotransmitters: A Narrative Review on Current Knowledge. Nutrients 10. doi:10.3390/NU10050591

Čermák, T., Baltes, N. J., Čegan, R., Zhang, Y., and Voytas, D. F. (2015). Highfrequency, Precise Modification of the Tomato Genome. Genome Biol. 16, 1-15. doi:10.1186/S13059-015-0796-9/TABLES/2

Chang, L., Wu, S., and Tian, L. (2019). Effective Genome Editing and Identification of a Regiospecific Gallic Acid 4-O-Glycosyltransferase in Pomegranate (Punica Granatum L). Hortic. Res. 6, 1-15. doi:10.1038/ s41438-019-0206-7

Clasen, B. M., Stoddard, T. J., Luo, S., Demorest, Z. L., Li, J., Cedrone, F., et al. (2016). Improving Cold Storage and Processing Traits in Potato through Targeted Gene Knockout. Plant Biotechnol. J. 14, 169-176. doi:10.1111/PBI. 12370

Collias, D., and Beisel, C. L. (2021). CRISPR Technologies and the Search for the PAM-free Nuclease. Nat. Commun. 121 (12), 1-12. doi:10.1038/s41467-02020633-y

Dahan-Meir, T., Filler-Hayut, S., Melamed-Bessudo, C., Bocobza, S., Czosnek, H., Aharoni, A., et al. (2018). Efficient in Planta Gene Targeting in Tomato Using Geminiviral Replicons and the CRISPR/Cas9 System. Plant J. 95, 5-16. doi:10. 1111/TPJ.13932

Demorest, Z. L., Coffman, A., Baltes, N. J., Stoddard, T. J., Clasen, B. M., Luo, S., et al. (2016). Direct Stacking of Sequence-specific Nuclease-Induced Mutations to Produce High Oleic and Low Linolenic Soybean Oil. BMC Plant Biol. 16, 1-8. doi:10.1186/S12870-016-0906-1/FIGURES/3

Deng, L., Wang, H., Sun, C., Li, Q., Jiang, H., Du, M., et al. (2018). Efficient Generation of Pink-Fruited Tomatoes Using CRISPR/Cas9 System. J. Genet. Genomics 45, 51-54. doi:10.1016/J.JGG.2017.10.002

Gago, C., Drosou, V., Paschalidis, K., Guerreiro, A., Miguel, G., Antunes, D., et al. (2017). Targeted Gene Disruption Coupled with Metabolic Screen Approach to Uncover the LEAFY COTYLEDON1-LIKE4 (L1L4) Function in Tomato Fruit Metabolism. Plant Cel Rep 36, 1065-1082. doi:10.1007/S00299-017-2137-9/ TABLES/3

González, M. N., Massa, G. A., Andersson, M., Turesson, H., Olsson, N., Fält, A. S., et al. (2020). Reduced Enzymatic Browning in Potato Tubers by Specific Editing of a Polyphenol Oxidase Gene via Ribonucleoprotein Complexes Delivery of

\section{AUTHOR CONTRIBUTIONS}

AN and HE conceived this mini review. AN and HE wrote the manuscript. All authors read and approved the final manuscript.

\section{FUNDING}

The Research in the Ezura group is funded by the following grants: Program on Open Innovation Platform with Enterprise, Research Institute and Academia, Japan Science and Technology Agency (JST-OPERA, JPMJOP 1 851).

\section{SUPPLEMENTARY MATERIAL}

The Supplementary Material for this article can be found online at: https://www.frontiersin.org/articles/10.3389/fgeed.2022.850104/ full\#supplementary-material

the CRISPR/Cas9 System. Front. Plant Sci. 10, 1649. doi:10.3389/FPLS.2019. 01649/BIBTEX

Gramazio, P., Takayama, M., and Ezura, H. (2020). Challenges and Prospects of New Plant Breeding Techniques for GABA Improvement in Crops: Tomato as an Example. Front. Plant Sci. 11, 1382. doi:10.3389/FPLS.2020.577980/BIBTEX

Haun, W., Coffman, A., Clasen, B. M., Demorest, Z. L., Lowy, A., Ray, E., et al. (2014). Improved Soybean Oil Quality by Targeted Mutagenesis of the Fatty Acid Desaturase 2 Gene Family. Plant Biotechnol. J. 12, 934-940. doi:10.1111/ PBI.12201

Hunziker, J., Nishida, K., Kondo, A., Kishimoto, S., Ariizumi, T., and Ezura, H. (2020). Multiple Gene Substitution by Target-AID Base-Editing Technology in Tomato. Sci. Rep. 10, 1-12. doi:10.1038/s41598-020-77379-2

Ito, Y., Nishizawa-Yokoi, A., Endo, M., Mikami, M., Shima, Y., Nakamura, N., et al. (2017). Re-evaluation of the Rin Mutation and the Role of RIN in the Induction of Tomato Ripening. Nat. Plants 311 (3), 866-874. doi:10.1038/s41477-017-0041-5

Jiang, M., Zhan, Z., Li, H., Dong, X., Cheng, F., and Piao, Z. (2020). Brassica Rapa Orphan Genes Largely Affect Soluble Sugar Metabolism. Hortic. Res. 7, 1-12. doi:10.1038/s41438-020-00403-z

Jinek, M., Chylinski, K., Fonfara, I., Hauer, M., Doudna, J. A., and Charpentier, E. (2012). A Programmable Dual-RNA-Guided DNA Endonuclease in Adaptive Bacterial Immunity. Science 80-337, 816-821. doi:10.1126/SCIENCE.1225829/ SUPPL_FILE/PAP.PDF

Karunarathna, N. L., Wang, H., Harloff, H. J., Jiang, L., and Jung, C. (2020). Elevating Seed Oil Content in a Polyploid Crop by Induced Mutations in SEED FATTY ACID REDUCER Genes. Plant Biotechnol. J. 18, 2251-2266. doi:10. 1111/PBI.13381

Kaur, N., Alok, A., Shivani, Kumar, P., Kaur, N., Awasthi, P., et al. (2020). CRISPR/ Cas9 Directed Editing of Lycopene Epsilon-Cyclase Modulates Metabolic Flux for $\beta$-carotene Biosynthesis in Banana Fruit. Metab. Eng. 59, 76-86. doi:10. 1016/J.YMBEN.2020.01.008

Klimek-Chodacka, M., Oleszkiewicz, T., Lowder, L. G., Qi, Y., and Baranski, R. (2018). Efficient CRISPR/Cas9-based Genome Editing in Carrot Cells. Plant Cel Rep 37, 575-586. doi:10.1007/S00299-018-2252-2/FIGURES/6

Li, A., Jia, S., Yobi, A., Ge, Z., Sato, S. J., Zhang, C., et al. (2018a). Editing of an Alpha-Kafirin Gene Family Increases, Digestibility and Protein Quality in Sorghum. Plant Physiol. 177, 1425-1438. doi:10.1104/PP.18.00200

Li, R., Li, R., Li, X., Fu, D., Zhu, B., Tian, H., et al. (2018b). Multiplexed CRISPR/ Cas9-mediated Metabolic Engineering of $\gamma$-aminobutyric Acid Levels in Solanum lycopersicum. Plant Biotechnol. J. 16, 415-427. doi:10.1111/PBI.12781

Li, T., Yang, X., Yu, Y., Si, X., Zhai, X., Zhang, H., et al. (2018c). Domestication of Wild Tomato Is Accelerated by Genome Editing. Nat. Biotechnol. 36, 1160-1163. doi:10.1038/nbt.4273 
Li, X., Wang, Y., Chen, S., Tian, H., Fu, D., Zhu, B., et al. (2018d). Lycopene Is Enriched in Tomato Fruit by CRISPR/Cas9-mediated Multiplex Genome Editing. Front. Plant Sci. 9, 559. doi:10.3389/FPLS.2018.00559/BIBTEX

Maioli, A., Gianoglio, S., Moglia, A., Acquadro, A., Valentino, D., Milani, A. M., et al. (2020). Simultaneous CRISPR/Cas9 Editing of Three PPO Genes Reduces Fruit Flesh Browning in Solanum Melongena L. Front. Plant Sci. 11, 1883. doi:10.3389/FPLS.2020.607161/BIBTEX

Manghwar, H., Li, B., Ding, X., Hussain, A., Lindsey, K., Zhang, X., et al. (2020). CRISPR/Cas Systems in Genome Editing: Methodologies and Tools for sgRNA Design, Off-Target Evaluation, and Strategies to Mitigate Off-Target Effects. Adv. Sci. 7, 1902312. doi:10.1002/ADVS.201902312

Matres, J. M., Hilscher, J., Datta, A., Armario-Nájera, V., Baysal, C., He, W., et al. (2021). Genome Editing in Cereal Crops: an Overview. Transgenic Res. 304, 461-498. doi:10.1007/S11248-021-00259-6

Modrzejewski, D., Hartung, F., Lehnert, H., Sprink, T., Kohl, C., Keilwagen, J., et al. (2020). Which Factors Affect the Occurrence of Off-Target Effects Caused by the Use of CRISPR/Cas: A Systematic Review in Plants. Front. Plant Sci. 11, 1838. doi:10.3389/FPLS.2020.574959/BIBTEX

Naegeli, H., Bresson, J. L., Dalmay, T., Dewhurst, I. C., Epstein, M. M., Firbank, L. G., et al. (2020). Applicability of the EFSA Opinion on Site-Directed Nucleases Type 3 for the Safety Assessment of Plants Developed Using Site-Directed Nucleases Type 1 and 2 and Oligonucleotide-Directed Mutagenesis. EFSA J. 18, e06299. doi:10.2903/J.EFSA.2020.6299

Nakayasu, M., Akiyama, R., Lee, H. J., Osakabe, K., Osakabe, Y., Watanabe, B., et al. (2018). Generation of $\alpha$-solanine-free Hairy Roots of Potato by CRISPR/Cas 9 Mediated Genome Editing of the St16DOX Gene. Plant Physiol. Biochem. 131, 70-77. doi:10.1016/J.PLAPHY.2018.04.026

Nieves-Cordones, M., Mohamed, S., Tanoi, K., Kobayashi, N. I., Takagi, K., Vernet, A., et al. (2017). Production of Low-Cs+ rice Plants by Inactivation of the K+ Transporter OsHAK1 with the CRISPR-Cas System. Plant J. 92, 43-56. doi:10. 1111/TPJ.13632

Nishida, K., Arazoe, T., Yachie, N., Banno, S., Kakimoto, M., Tabata, M., et al. (2016). Targeted Nucleotide Editing Using Hybrid Prokaryotic and Vertebrate Adaptive Immune Systems. Science 80, 353. doi:10.1126/SCIENCE.AAF8729/ SUPPL_FILE/PAP.PDF

Nonaka, S., Arai, C., Takayama, M., Matsukura, C., and Ezura, H. (2017). Efficient Increase of $\gamma$-Aminobutyric Acid (GABA) Content in Tomato Fruits by Targeted Mutagenesis. Sci. Rep. 7, 1-14. doi:10.1038/s41598-017-06400-y

Okuzaki, A., Ogawa, T., Koizuka, C., Kaneko, K., Inaba, M., Imamura, J., et al. (2018). CRISPR/Cas9-mediated Genome Editing of the Fatty Acid Desaturase 2 Gene in Brassica Napus. Plant Physiol. Biochem. 131, 63-69. doi:10.1016/J. PLAPHY.2018.04.025

Osakabe, K., Wada, N., Miyaji, T., Murakami, E., Marui, K., Ueta, R., et al. (2020). Genome Editing in Plants Using CRISPR Type I-D Nuclease. Commun. Biol. 31 (3), 1-10. doi:10.1038/s42003-020-01366-6

Qiu, Z., Wang, H., Li, D., Yu, B., Hui, Q., Yan, S., et al. (2019). Identification of Candidate HY5-Dependent and -Independent Regulators of Anthocyanin Biosynthesis in Tomato. Plant Cel Physiol 60, 643-656. doi:10.1093/PCP/ PCY236

Ren, C., Liu, X., Zhang, Z., Wang, Y., Duan, W., Li, S., et al. (2016). CRISPR/Cas9mediated Efficient Targeted Mutagenesis in Chardonnay (Vitis vinifera L). Sci. Rep. 6, 1-9. doi:10.1038/srep32289

Rojas-Vásquez, R., and Gatica-Arias, A. (2019). Use of Genome Editing Technologies for Genetic Improvement of Crops of Tropical Origin. Plant Cell, Tissue Organ. Cult. 140, 215-244. doi:10.1007/S11240-019-01707-2

Sakata, R. C., Ishiguro, S., Mori, H., Tanaka, M., Seki, M., Masuyama, N., et al. (2019). A Single CRISPR Base Editor to Induce Simultaneous C-To-T and A-To-G Mutations. bioRxiv, 729269. doi:10.1101/729269

Sánchez-León, S., Gil-Humanes, J., Ozuna, C. V., Giménez, M. J., Sousa, C., Voytas, D. F., et al. (2018). Low-gluten, Nontransgenic Wheat Engineered with CRISPR/Cas9. Plant Biotechnol. J. 16, 902-910. doi:10.1111/PBI. 12837
Sun, B., Jiang, M., Zheng, H., Jian, Y., Huang, W. L., Yuan, Q., et al. (2020). Color-related Chlorophyll and Carotenoid Concentrations of Chinese Kale Can Be Altered through CRISPR/Cas9 Targeted Editing of the Carotenoid Isomerase Gene BoaCRTISO. Hortic. Res. 7, 1-11. doi:10.1038/s41438-020-00379-w

Sun, Y., Jiao, G., Liu, Z., Zhang, X., Li, J., Guo, X., et al. (2017). Generation of HighAmylose rice through CRISPR/Cas9-mediated Targeted Mutagenesis of Starch Branching Enzymes. Front. Plant Sci. 8, 298. doi:10.3389/FPLS.2017.00298/ BIBTEX

Tikunov, Y. M., Roohanitaziani, R., Meijer-Dekens, F., Molthoff, J., Paulo, J., Finkers, R., et al. (2020). The Genetic and Functional Analysis of Flavor in Commercial Tomato: the FLORAL4 Gene Underlies a QTL for floral Aroma Volatiles in Tomato Fruit. Plant J. 103, 1189-1204. doi:10.1111/TPJ.14795

Waltz, E. (2016a). CRISPR-edited Crops Free to Enter Market, Skip Regulation. Nat. Biotechnol. 34, 582. doi:10.1038/nbt0616-582

Waltz, E. (2016b). Gene-edited CRISPR Mushroom Escapes US Regulation. Nature 532, 293. doi:10.1038/NATURE.2016.19754

Wang, H., Wu, Y., Zhang, Y., Yang, J., Fan, W., Zhang, H., et al. (2019). CRISPR/ Cas9-Based Mutagenesis of Starch Biosynthetic Genes in Sweet Potato (Ipomoea Batatas) for the Improvement of Starch Quality. Int. J. Mol. Sci. 20, 4702. doi:10.3390/IJMS20194702

Wen, S., Liu, H., Li, X., Chen, X., Hong, Y., Li, H., et al. (2018). TALEN-mediated Targeted Mutagenesis of Fatty Acid Desaturase 2 (FAD2) in Peanut (Arachis hypogaea L.) Promotes the Accumulation of Oleic Acid. Plant Mol. Biol. 97, 177-185. doi:10.1007/S11103-018-0731-Z/FIGURES/5

Yan, S., Chen, N., Huang, Z., Li, D., Zhi, J., Yu, B., et al. (2020). Anthocyanin Fruit Encodes an R2R3-MYB Transcription Factor, SIAN2-like, Activating the Transcription of SIMYBATV to fine-tune Anthocyanin Content in Tomato Fruit. New Phytol. 225, 2048-2063. doi:10.1111/NPH.16272

Yuan, M., Zhu, J., Gong, L., He, L., Lee, C., Han, S., et al. (2019). Mutagenesis of FAD2 Genes in Peanut with CRISPR/Cas9 Based Gene Editing. BMC Biotechnol. 19, 1-7. doi:10.1186/S12896-019-0516-8/FIGURES/2

Zhang, H., Si, X., Ji, X., Fan, R., Liu, J., Chen, K., et al. (2018). Genome Editing of Upstream Open reading Frames Enables Translational Control in Plants. Nat. Biotechnol. 36, 894-898. doi:10.1038/nbt.4202

Zhi, J., Liu, X., Li, D., Huang, Y., Yan, S., Cao, B., et al. (2020). CRISPR/Cas9mediated SIAN2 Mutants Reveal Various Regulatory Models of Anthocyanin Biosynthesis in Tomato Plant. Plant Cel Rep 39, 799-809. doi:10.1007/S00299020-02531-1/FIGURES/5

Zhu, Z., Sun, B., Cai, W., Zhou, X., Mao, Y., Chen, C., et al. (2019). Natural Variations in the MYB Transcription Factor MYB31 Determine the Evolution of Extremely Pungent Peppers. New Phytol. 223, 922-938. doi:10.1111/NPH. 15853

Zsögön, A., Čermák, T., Naves, E. R., Notini, M. M., Edel, K. H., Weinl, S., et al. (2018). De Novo domestication of Wild Tomato Using Genome Editing. Nat. Biotechnol. 36, 1211-1216. doi:10.1038/nbt.4272

Conflict of Interest: The authors declare that the research was conducted in the absence of any commercial or financial relationships that could be construed as a potential conflict of interest.

Publisher's Note: All claims expressed in this article are solely those of the authors and do not necessarily represent those of their affiliated organizations, or those of the publisher, the editors and the reviewers. Any product that may be evaluated in this article, or claim that may be made by its manufacturer, is not guaranteed or endorsed by the publisher.

Copyright () 2022 Nagamine and Ezura. This is an open-access article distributed under the terms of the Creative Commons Attribution License (CC BY). The use, distribution or reproduction in other forums is permitted, provided the original author(s) and the copyright owner(s) are credited and that the original publication in this journal is cited, in accordance with accepted academic practice. No use, distribution or reproduction is permitted which does not comply with these terms. 